Systematic Review

\title{
Evaluation of Diagnostic Performance of Automatic Breast Volume Scanner Compared to Handheld Ultrasound on Different Breast Lesions: A Systematic Review
}

\author{
Shahad A. Ibraheem ${ }^{1, *}$, Rozi Mahmud ${ }^{1,2}$, Suraini Mohamad Saini ${ }^{1,2}$, Hasyma Abu Hassan ${ }^{1}$, \\ Aysar Sabah Keiteb ${ }^{3}$ and Ahmed M. Dirie ${ }^{4}$ \\ 1 Department of Radiology, Faculty of Medicine and Health Sciences, Universiti Putra Malaysia, \\ Serdang 43400, Malaysia; rozi@upm.edu.my (R.M.); surainims@upm.edu.my (S.M.S.); \\ hasyma@upm.edu.my (H.A.H.) \\ 2 Centre for Diagnostic Nuclear Imaging, Universiti Putra Malaysia, Serdang 43400, Malaysia \\ 3 Department of Radiological Techniques, College of Health and Medical Technologies, Baghdad 10047, Iraq; \\ aysarph.d@gmail.com \\ 4 Department of Community Health, Faculty of Medicine and Health Sciences, Universiti Putra Malaysia, \\ Serdang 43400, Malaysia; diiriyenih@gmail.com \\ * Correspondence: gs52320@student.upm.edu.my
}

check for updates

Citation: Ibraheem, S.A.; Mahmud, R.; Mohamad Saini, S.; Abu Hassan,

H.; Keiteb, A.S.; Dirie, A.M.

Evaluation of Diagnostic

Performance of Automatic Breast Volume Scanner Compared to Handheld Ultrasound on Different Breast Lesions: A Systematic Review. Diagnostics 2022, 12, 541. https:// doi.org/10.3390/diagnostics12020541

Academic Editors: Cecilia Di Ruberto, Alessandro Stefano, Albert Comelli, Lorenzo Putzu and Andrea Loddo

Received: 10 January 2022

Accepted: 25 January 2022

Published: 19 February 2022

Publisher's Note: MDPI stays neutral with regard to jurisdictional claims in published maps and institutional affiliations.

Copyright: (C) 2022 by the authors. Licensee MDPI, Basel, Switzerland. This article is an open access article distributed under the terms and conditions of the Creative Commons Attribution (CC BY) license (https:// creativecommons.org/licenses/by/ $4.0 /)$.

\begin{abstract}
Objective: To compare the diagnostic performance of the automatic breast volume scanner (ABVS) against the handheld ultrasound (HHUS) in the differential diagnosis of benign and malignant breast lesions. Methods: A systematic search and review of studies involving ABVS and HHUS for breast cancer screening were performed. The search involved the data taken from Scopus, PubMed, and science direct databases and was conducted between the year 2011 to 2020 . The prospective method was used in determining the inclusion and exclusion criteria while the evidence level was determined using the BI-RADS categories for diagnostic studies. In addition, the parameters of specificity, mean age, sensitivity, tumor number, and diagnostic accuracy of the ABVS and HHUS were summarized. Results: No systematic review or randomized controlled trial were identified in the systematic search while one cross-sectional study, eight retrospective studies, and 10 prospective studies were found. Sufficient follow-up of the subjects with benign and malignant findings were made only in 10 studies, in which only two had used ABVS and HHUS after performing mammographic screening and MRI. Analysis was made of 21 studies, which included 5448 lesions (4074 benign and 1374 malignant) taken from 6009 patients. The range of sensitivity was (0.72-1.0) for ABVS and (0.62-1.0) for HHUS; the specificity range was $(0.52-0.98) \%$ for ABVS and $(0.49-0.99) \%$ for HHUS. The accuracy range among the 11 studies was (80-99)\% and (59-98)\% for the HHUS and ABVS, respectively. The identified tumors had a mean size of $2.1 \mathrm{~cm}$, and the detected cancers had a mean percentage of $94 \%(81-100) \%$ in comparison to the non-cancer in all studies. Conclusions: The evidence available in the literature points to the fact that the diagnostic performance of both ABVS and HHUS are similar with reference to the differentiation of malignant and benign breast lesions.
\end{abstract}

Keywords: handheld ultrasound; BI-RADS; automatic breast volume scanner; breast cancer

\section{Introduction}

Breast disease is common among modern women. It is also one of the leading diseases that threatens the physical health of women. The American Cancer Society predicted that the United States would top the ranking, with 276,480 women with breast cancer in 2020 in the country alone, which accounted for $30 \%$ of all cancer patients. With the death of 42,170 of these women, it ranked in second place by accounting for $15 \%$ of cancer deaths [1]. In Malaysia, breast cancer is the leading type of cancer, which accounted for $34.1 \%$ of all cancer cases in the female population. The diagnosis of a total of 21,634 female breast 
cancer cases were made between 2012 and 2016, compared to 18,206 cases in the report of 2007-2011. Nonetheless, $19.0 \%$ of all new diagnosis of cancer cases between 2012-2016 in comparison to $17.7 \%$ in 2007-2011 was attributed to breast cancer, in spite of gender. There has been an increase of $2 \%$ for overall cancer among women in a similar comparative period, from $32.1 \%$ to $34.1 \%$, for new cases of breast cancer [2].

However, the ideal breast screening system is yet undetermined. Mammography has for some time been the only suggestion for breast screening imaging assessment, and has shown brilliant affectability and particularity. Nonetheless, its utilization in young women under 40 years of age is restricted due to radiation concerns and, often, thick breasts. Presently, there has been a decline in the once-demonstrated power of yearly mammography screening in decreasing the rate of mortality related to breast cancer [3]. The overall clinical limitation of breast screening is similarity in magnetic resonance imaging (MRI) due to inadequate particularity and inadmissible accessibility to non-wealthy regions and individuals [4].

Apart from the obvious benefit of ultrasound in breast cancer diagnosis, it is also beneficial in complementing diagnostic mammograms. It is safe and sensitive at distinguishing the echo of gland tissue and fat, and is good at defining the boundary and morphology of lesions [5-7]. Despite the benefits, the duration of the whole-breast examination and operator dependence has rendered the conventional handheld ultrasound (HHUS) with a number of inherent limitations [8]. In contrast, shorter duration of image acquisition, higher reproducibility, and less operator dependence of the automated breast volume scanner (ABVS) has given it a number of advantages over the HHUS [9,10]. Besides, extra information on the diagnosis of the coronal plane that has been reconstructed can also be obtained from the ABVS. Hence, these advantages render the ABVS a promising method for the imaging of breasts in screening as well as diagnostic settings [11,12]. ABUS offers reproducible, high-resolution images and does not depend on the operator, and is achieved using an automated scanner with a larger field of view. Numerous prospective studies have described that adding mammography to ABUS screening resulted in similar positive outcomes to those linked with HHUS screening, such as increased discovery of invasive cancer and reduced rates of interval cancer [5].

In 2012, the approval for the use of ABVS was granted by the U.S. Food and Drug Administration for women with dense breasts and negative mammography findings as an additional whole-breast screening method [13]. The use of ABVS for diagnostic purposes has, over the past decade, been examined by different studies [9,14-17]. Promising results have been reported in several considerably small patient-population studies [15,18-20]. However, the differentiation and characterization of breast lesion discovered through mammography or other screening technologies in present day clinical practice are conducted by a majority of radiologists with the use of conventional HHUS. The controversy regarding the diagnostic performance of ABVS in contrast to HHUS remains. Hence, a systematic review of the differential diagnosis of breast lesions was conducted, comparing HHUS and ABVS diagnostic performance.

\section{Materials and Methods}

\subsection{Search Strategy}

A strategy was developed for a systematic search to distinguish significant literature. The search strategy was customized to three databases, namely PubMed, Scopus, and science direct, while the inquiry terms 'automated breast ultrasound', 'handheld ultrasound', and 'breast cancer' were utilized. In particular, all literature was included with reference to automated breast ultrasound (which included its synonyms, for example, automated breast sonography, automated breast scanner, automated whole breast ultrasound, automated breast image, automated whole breast volume scan, 3D automated breast ultrasound, automated breast volume ultrasonography) and handheld (handheld, handheld, handheld, portable, or pocket). The search also spanned the period from the inception of the database to 2020, with the inclusion of journal articles published solely in English. 


\subsection{Selection Criteria}

The criteria for selection depended on the PRISMA Statement [21]. The search mainly focused on the mapping of existing literature on automated breast ultrasound in contrast to handheld ultrasound in medicine, biochemistry, genetics, molecular biology, and the health professions. The search then narrowed down to the medical field. The search span was made between 2011-2020. All articles before 2011 were excluded. The search was not limited to any specific countries, therefore there was no exclusion in this option. The following are the inclusion criteria: (1) both ABVS and HHUS were used in breast lesion diagnosis; (2) the ABVS method was financially accessible; (3) the study population was made up of a minimum of 20 patients; (4) follow-up of histologic analysis (surgery or biopsy), and clinical/imaging for a minimum of 1 year, and unchanged lesions were viewed as pathologically benign. Screening of the relevant literature's abstracts and titles were conducted, and inspection of the full texts was performed by two researchers independently in determining the inclusion of selected articles in the analysis. A consensus was used in resolving any conflict between the two researchers. At this stage, a total of 311 research articles were excluded while 414 records were extricated.

\subsection{Data Extraction}

Data collection was made regarding the year of publication, the country in which the examination was performed, the objectives, study design, number of participants, screening methods of assessment, patients' mean age, and the number of lesions.

\subsection{Quality Assessment}

Conference papers, original research articles, and review papers became the basis of this study. A thorough check was made on all duplications in maintaining the nature of the review. In ensuring the relevance and quality of the academic literature included in the review process, detailed examination of the abstracts of articles was conducted in the process of analysis and purification. Next, careful assessment of each research paper was performed. To limit the research only to English-published papers, the subsequent exclusion criterion was therefore used. Therefore, three articles in languages other than English have not been included in the study. In addition to that, the filtration of duplicate records resulted in the removal of 65 more articles. The assessment of each article based on the inclusion and exclusion criteria above resulted in the selection of 21 articles. The exclusion and inclusion of the literature at every stage (PRISMA Statement) is shown in Figure 1. Assessment of the methodological quality was made by two independent reviewers, and to resolve any dispute between the reviewers, mutual suggestion was used. For the inclusion of studies regarding 'diagnostic accuracy', the QUADAS-2 (Quality Assessment of Diagnostic Accuracy Studies-2) tool was used which involved four domains including 'index test', 'reference standard', 'patient selection', and 'flow and timing' [22] (Table 1). Evaluation was made of each domain with regard to its risk of bias (low, high, or unclear), and the initial three domains were identified with regard to their applicability. In general, a study that is viewed as "low" in all domains regarding its applicability or bias is deemed appropriate for an overall judgment of "low concern regarding applicability" or "low risk of bias" for the study. However, judgement of a study is made as having "concerns regarding applicability" or "at risk of bias" if viewed as "unclear" or "high" in one or more domains. Dispute between the two reviewers in assessing the quality of the study was settled through discussion (Figure 2). 


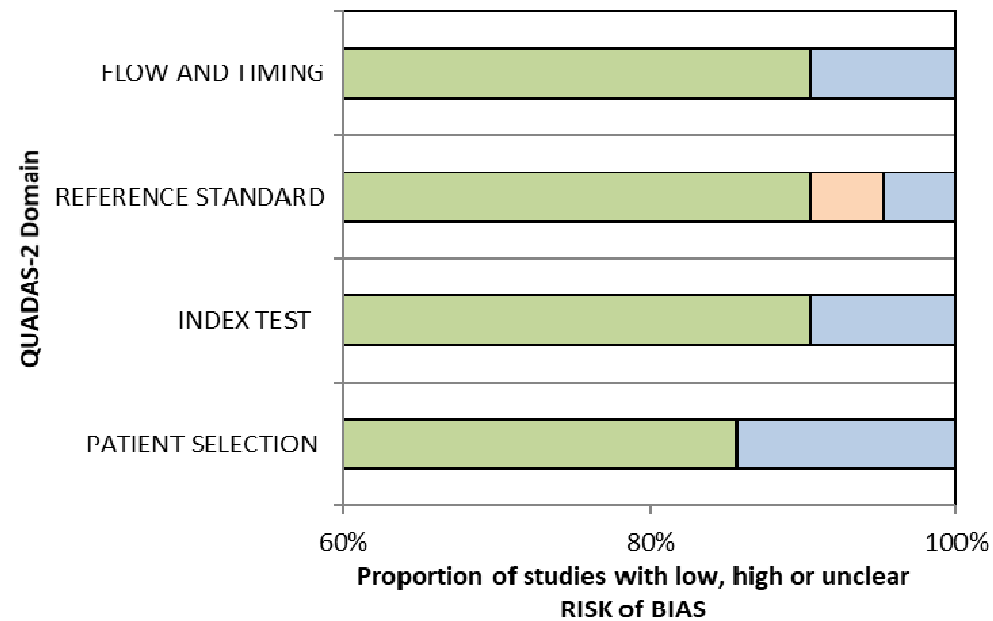

口Low $\square$ High $\square$ Unclear

Figure 1. Bar charts for Quality Assessment of Diagnostic Accuracy Studies-2 (QUADAS-2) analysis for 21 studies of diagnostic accuracy.

Table 1. Quality of studies included in diagnostic accuracy analysis for risk of bias and applicability concerns.

\begin{tabular}{|c|c|c|c|c|c|c|c|}
\hline \multirow[b]{2}{*}{ Study } & \multicolumn{4}{|c|}{ Risk Of Bias } & \multicolumn{3}{|c|}{ Applicability Concerns } \\
\hline & $\begin{array}{c}\text { Patient } \\
\text { Selection }\end{array}$ & Index Test & $\begin{array}{l}\text { Reference } \\
\text { Standard }\end{array}$ & $\begin{array}{c}\text { Flow and } \\
\text { Timing }\end{array}$ & $\begin{array}{c}\text { Patient } \\
\text { Selection }\end{array}$ & Index Test & $\begin{array}{l}\text { Reference } \\
\text { Standard }\end{array}$ \\
\hline Depretto et al., 2020 & ;:) & ;:) & ;) & ;: & ;) & ;) & ;:) \\
\hline Jia et al., 2020 & : & (;) & ;) & $?$ & ;) & (:) & ;) \\
\hline Tutar et al., 2020 & ;) & ;) & ;) & $?$ & ;) & ;) & ;) \\
\hline Yun et al., 2019 & (;) & (;) & (;) & (;) & (;) & (;) & ;:) \\
\hline Zhang et al., 2019 & $?$ & (:) & ;) & (:) & (:) & (:) & ;:) \\
\hline Niu et al., 2019 & (:) & (:) & (:) & ;) & (:) & (:) & ;:) \\
\hline Choi et al., 2018 & (;) & (;) & (;) & (;) & (;) & (;) & (:) \\
\hline Zhang et al., 2018 & ;) & (:) & (:) & (:) & (:) & (;) & (:) \\
\hline Schmachtenberg et al., 2017 & (;) & (;) & (;) & (;) & (;) & (;) & (:) \\
\hline Hellgren et al., 2016 & ;) & ;) & (;) & ;) & (:) & (:) & (:) \\
\hline Kim et al., 2016 & $?$ & $?$ & (:) & (;) & ;) & $?$ & (:) \\
\hline Jeh al., 2015 & (:) & ;:) & $?$ & ;) & ;: & (:) & $?$ \\
\hline Chio et al., 2014 & ;) & (;) & (;) & (;) & $?$ & (;) & (:) \\
\hline Kim et al., 2013 & (:) & $?$ & (:) & (;) & (;) & $?$ & (:) \\
\hline Chen et al., 2013 & $?$ & (:) & (:) & (:) & (:) & (:) & (:) \\
\hline Lin et al., 2012 & (:) & ;) & (:) & ;) & (;) & $?$ & ;) \\
\hline Wang et al., 2012 & ;) & ;) & ;) & ;) & ;:) & ;: & ;:) \\
\hline Wojcinski et al., 2011 & ;) & ;: & ;) & ;) & ;: & ;:) & (:) \\
\hline Chang et al., 2011 & ;) & ;) & ;) & ;) & ;: & ;) & ;:) \\
\hline Shin et al., 2011 & ;) & (:) & (;) & (;) & (:) & (:) & (:) \\
\hline
\end{tabular}

;) Low Risk :) High Risk ? Unclear Risk. 

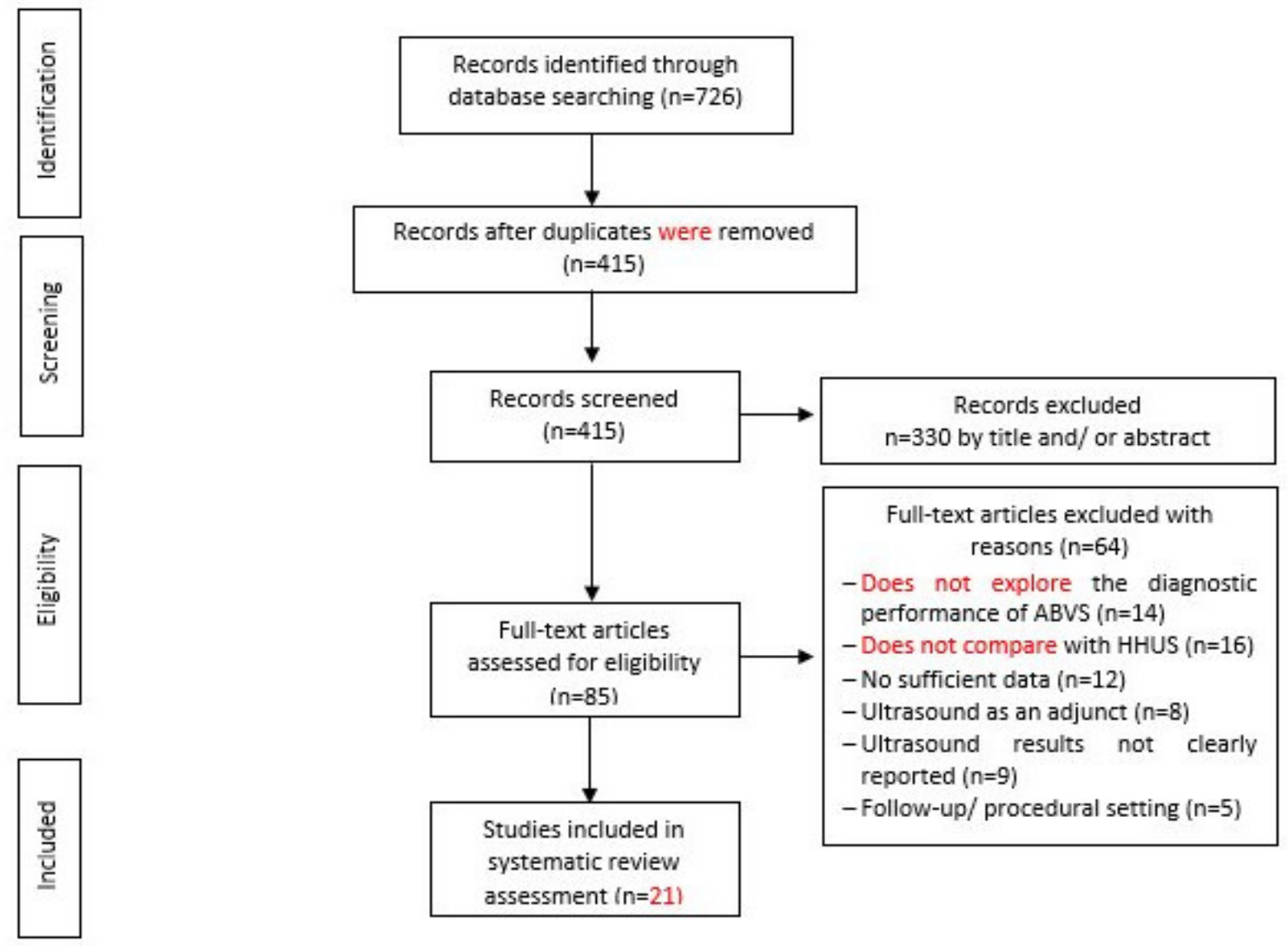

Figure 2. Flow Chart of Study Selection.

\section{Results}

\subsection{Search Strategy and Study Selection}

Based on the search strategy, 726 records were discovered from the electronic databases when, due to duplication issues, 311 items were then discarded. The screening of titles and abstracts based on the inclusion criteria resulted in the exclusion of another 320 items. By reading the full content, 64 more items were excluded based on the examination of the remaining 85 articles. The final selection to be included in the literature review of this study included 21 studies (Depretto et al., 2020; Jia et al., 2020; Tutar et al., 2020; Yun et al., 2019; Zhang et al., 2019; Niu et al., 2019; Choi et al., 2018; Zhang et al., 2018; Schmachtenberg et al., 2017; Hellgren et al., 2016; Kim et al., 2016; Jeh et al., 2015; Choi et al., 2014; Chen et al., 2013; Kim et al., 2013; Lin et al., 2012; Wang et al., 2012; Wojcinski et al., 2011; Chang et al., 2011; Shin et al., 2011). The screening of the included studies' reference list marks the end of the process of inclusion of studies. A summary of the process involved in the studies selected for the inclusion of this review is shown in the flowchart (see Figure 2).

\subsection{Characteristics of the Study and Quality Assessment}

From the 21 studies, the inclusion of 5448 lesions in 6009 patients was made, whereby 1374 (23.3\%) were malignant while 4074 (69.1\%) were benign. Three brands of the ABVS were discovered; ACUSON S2000 (Siemens Healthcare, Erlangen, Germany) as the highestutilized brand among 13 studies, InveniaTM (GE Healthcare, WI, USA) as the second highest utilized brand among five studies, and SomoVu Scan Station (Usystem, Inc., San Jose, CA, USA), found in three studies although five brands of the HHUS were discovered; ACUSON S2000 ${ }^{\mathrm{TM}}$; Siemens, Erlangen, Germany as the highest-utilized brand among 8 studies, iU22 Ultrasound System (Philips Medical System, WA, USA) as the second highest utilized brand among 7 studies, Logiq E9 (GE Healthcare; Milwaukee, WI, USA) 
utilized among three studies, EUB-8500 scanner (Hitachi Medical, Tokyo, Japan) used in two study while Aplio 80 (Toshiba, Tokyo, Japan) just in one study.

Among 14 studies, the sensitivity range was (0.72-1.0) for ABVS and (0.62-1.0) for HHUS, while the specificity range was $(0.52-0.98)$ for ABVS and (0.49-0.99) for HHUS. Among the 11 studies, the accuracy range was (59-98)\% and (80-99)\% for ABVS and HHUS, respectively. ABVS and HHUS were utilized in 21 studies, thus giving unbiased, extractable data in terms of diagnostic accuracy. For the 21 studies on 'diagnostic accuracy', the results of histopathology assessment were the standard of reference. 'Lesion by lesion' is the rater approach chosen in all studies. The raters evaluated each lesion detected for malignancy using the BI-RADS. Table 1 provides the summary of the details of the study characteristics. As demonstrated by the QUADAS-2 tool, most of the studies (15 out of 21) had a rather high methodological quality (Table 2). However, due to the use of case-control configuration in this study, one study was judged as high risk [23]. As a result of imprecise review of HHUS and ABVS images, the same radiologist judged five studies as unclear risk, with the use of the blinding method.

\subsection{Age Distribution}

The report of 18 studies showed an age range between 11 to 82 years old, with the overall age range exceeding 30 years old in every study. Information on the median age was provided in three studies (49, 49, and 52 years), with age range between 32 to 82 years [24-26] (Table 2).

\subsection{Breast Lesion Diagnosis Using the Categories of BI-RADS}

Two studies separated the HHUS and ABVS outcome of breast screening according to the BI-RADS 4 and BI-RADS 5 classification [25,27]. Other studies assessed the results of breast tissue according to BI-RADS 1-BI-RADS 5. Females with BI-RADS 4 and BI-RADS 5 breast categories demonstrated the largest proportion of breast cancer diagnosed through ultrasound screening. Depretto et al. analyzed four carcinomas distinguished by (BI-RADS 4) breast tissue, and 130 cases with breasts in categories (BI-RADS 1 and BI-RADS 2) [28], and 29 malignancies were diagnosed in type 4 and type 5 BI-RADS breast tissue in Jia et al., while two carcinomas were found in three breasts [23].

Using the ABVS, the discovery of 51 circumscribed solid nodules (BI-RADS 3) were made in 42 women. The HHUS exhibited five of these as complicated cysts. The primary HHUS missed five nodules. However, the detection of five BI-RADS 3 solid nodules, one BI-RADS 2 implant rupture, and one BI-RADS 4 distortion was made by HHUS, which were all missed by ABVS. Altogether, 78 lesions were found in 340 women, 71 (91\%) of the detected nodules were discovered by ABVS while 68 (87.2\%) of the detection was made by the primary HHUS [24]. Niu et al. included 599 masses detected in 398 women (which included solid and cystic masses). The classification of 359 masses by the HHUS and ABUS as category 2 or 3 indicated these as benign masses. The MRI classified two of these masses as category 4 or 5 [29].

It was found at the completion of the study that 496 (83\%) of the 599 masses were benign while the remaining $103(17 \%)$ were malignant, with the one-year follow-up information or pathological outcomes as the reference standards. As indicated by the BI-RADS classification for every unit, 258 units $(258 / 320,80.63 \%)$ had BI-RADS classification 1-2, 62 units $(19.38 \%)$ had BI-RADS classification 3 while 155 lesions had the introductory BI-RADS classifications of 4-5 [30]. Choi et al. confirmed 184 malignant cases of BI-RADS 4 and BI-RADS 5 classes, and 234 lesions were diagnosed as benign (BI-RADS 3) [31]. The remaining 413 lesions were assigned as BI-RADS class $3(n=292)$ or $2(n=121)$. In a study conducted by Zhang et al., 1353 females (68.6\%) were characterized as BI-RADS 1, 2, or 3 categories while the other 620 females (31.4\%) were classified as BI-RADS category 4 or 5 [32]. 
Table 2. Characteristics of the included studies.

Author

Study Design/Objectives/Participants

Study design = prospective study

\section{Objective}

- To prospectively compare between the automated breast volumetric scanning (ABVS) with the hand-held bilateral whole breast ultrasound (HHUS) in lesion

Tutar et al., 2020

Turke

Participants $=345$ women

Age range $=$ between 35 to 67 years old (median

49-year-old)
Variables $=$ Breast cancer, Breast ultrasonography

Automated ultrasound, Mass screening.

\section{Study design $=$ Retrospective study}

- To examine the agreement between the hand-held ultrasound (HHUS) and the automated breast ultrasound (ABUS) in monitoring of women with breast cance

Depretto et al., 202 history, with regard to the contralateral ipsilateral

Italy

Participants $=154$ women

Age range $=$ aged between $34-90$ years old

ing, Breast oncology,

Study design $=$ Cross-sectional

- To determine, both in combination with mammography and separately, the diagnostic performance of the automated breast ultrasound system (ABUS) and the handheld ultrasound (HHUS) in dense

Jia et al., 2020 reasts Chinese women.

Participants $=1973$ wome

Age range $=$ Between $30-69$ years, mean age

Variables $=$ Breast density, Mammography, Breas

neoplasms, Ultrasonography.

Screening Method

Findings

Outcome

- Recall rate was $46 / 340$ (13.05\%) for ABVS

$>\quad$ and $4 / 340(1.18 \%)$ for HHUS.

Screening device

ABVS with integrated 14L5BV linear transducer

$(15.4 \mathrm{~cm})$

HHU win 145 (5-14 MHz) or 9L4 (4-9 MHz) linear transducer

Duration = Between May 2014 and July 2015

Follow up $=$ minimum 36 months

Interpreting Image $=$ BI-RADS US lexicon (BI-RADS 1-2) while ABVS had higher

results of false positives $(p<0.001)$.

$4.17 \%$ while HHUS had $50 \%$. irregular nodules of $(p<0.001)$, distortion of $(p<0.034)$, and over diagnosed

shadowing of $(p<0.01)$

$>\quad 59.7 \%$ of the women mentioned that if they had a choice, they would have chosen

HHUS. $10.6 \%$ of the women experienced severe pain from the use of ABVS

\section{Screening device $=$}

- The Selenia Dimension mammography system was used in conducting the mammography (Hologic; Bedford, MA)

- ABVS with a 6-14 MHz frequency.

6-15 MHz transducer.

Duration $=$ Between April to June 201

Follow up $=18$ to 24 months

Interpreting Image $=$ BI-RADS US lexico
ABUS and HHUS were substantial for ichotomic assessment $(\kappa=0.794)$ and for There was a significant difference

fference in assigning the BI-RADS categories $(p<0.05)$ though there was no difference in dichotomic assignment between 2 readers $(p=0.5)$. $\checkmark$ The use of ABVS in lesion detection is as

good as HHUS

call rate and lower positive predictive value. This could end up for the women.

$\checkmark$ Had they been given the choice, more than $50 \%$ of the women would have preferred HHUS.

thial agreement was achieved between ABUS and HHUS in monitoring of women with breast cancer history.

In particular, the ABUS could be used in first-level monitoring of intermediate risk women since it could recognize all cancers detected by HHUS.

\section{Screening device $=$}

$>\quad$ The mammograms were acquired using the Fujifilm FDR MS-2500 (Fujifilm Crop., Tokyo, Japan), GE Sengraphe DS (GE Healthcare, WI, USA), and Hologic Selenia (Hologic, MA, USA).

- The HHUS images were obtained using the Aixplorer system (Supersonic Imagine, Aix-en-Provence, France), GE LOGIQ9 (GE (Philips Medical SyA, iU22 Ul USA ) System (Siemens Medical Solutions, CA, USA).

- All ABUS scans were acquired using the Invenia ABUS (GE Healthcare, WI, USA)

Duration = Between February 2016 and March 2017

Follow up $=\mathrm{NP}$
Interpreting Image $=$ BI-RADS US lexicon
$>$ In mammography-negative dense breasts, the rate for incremental cancer detection the rate for incremental cancer det
was 42.8 for each 1000 ultrasound was 42.8 for each

$>$ The combination of HHUS or ABUS with mammography produced a sensitivity of $99.1 \%(219 / 221)$, and the specificities were $84.9 \%(608 / 716)$ and $86.9 \%(622 / 716)$,

$>\quad$ The combination of the HHUS with mammography produced a 0.92 area unde the curve, while a combination of ABUS

- With mammography produced one at 0.93 . in agreast cancer detection between HHUS and ABUS was observed (percent agreement $=0.94, \mathrm{~K}=0.85$ ). $\checkmark$ As adjuncts to mammography, both the HHUS and ABUS can substantially increase the rate of breast cancer detection in dense between them.

$\checkmark$ With various benefits of the ABUS ove HHUS, for instance reproducibility and les operator dependence, and the commonness of dense breasts, the use of ABUS in the early detection of breast cancer, especially in areas that have limited resources, has shown great potential. 
Table 2. Cont.

\begin{tabular}{|c|c|c|c|c|}
\hline Author & Study Design/Objectives/Participants & Screening Method & Findings & Outcome \\
\hline $\begin{array}{c}\text { Yun et al., } 2019 \\
\text { Korea }\end{array}$ & $\begin{array}{l}\text { Study design = Retrospective } \\
\text { Objectives } \\
\text { - In terms of the assessment of Breast Imaging } \\
\text { Reporting and Data System (BI-RADS) } \\
\text { category- to assess the reliability of } \\
\text { suspicious breast masses examination } \\
\text { performed using the automated breast } \\
\text { ultrasound (ABUS) as opposed to the } \\
\text { handheld breast ultrasound (HHUS). } \\
\text { To examine factors that affect categorization } \\
\text { discrepancies. } \\
\text { Participants = } 135 \text { patients } \\
\text { Age range = between } 34-90 \text { years old (mean } \pm \text { SD } \\
62 \pm 11 \text { years) } \\
\text { Variables = Breast Imaging Reporting and Data } \\
\text { System, Breast neoplasms, Automated breast } \\
\text { ultrasound, Hand-held ultrasound }\end{array}$ & $\begin{array}{l}\text { Screening device = } \\
\quad \text { ABUS exams } \\
\text { HHUS images were acquired using the linear } \\
\text { transducer at } 7-15 \mathrm{MHz} \\
\text { Duration = Between July } 2016 \text { and December } 2016 \\
\text { Follow up = NP } \\
\text { Interpreting Image = BI-RADS US lexicon }\end{array}$ & $\begin{array}{l}\text { There was an overall good agreement in all } \\
\text { cases between HHUS and ABUS ( } 79.3 \%, \\
\text { kappa }=0.61, p<0.001) \text {. } \\
\text { It was revealed in the logistic regression } \\
\text { analysis that differences in the } \\
\text { categorization of BI-RADS were associated } \\
\text { with the suspicious presence of } \\
\text { microcalcification on the mammography } \\
\text { (odds ratio [OR], } 4.63 ; 95 \% \text { confidence } \\
\text { interval (CI), } 1.83 \text { to } 11.71 ; p=0.001) \text { and an } \\
\text { irregular shape on US (OR, } 5.59 ; 95 \% \text { CI, } \\
1.43 \text { to } 21.83 ; p=0.013) .\end{array}$ & $\begin{array}{l}\text { The examination of suspicious breast } \\
\text { masses under the categorization of } \\
\text { BI-RADS have demonstrated good } \\
\text { agreement between HHUS and ABUS. } \\
\text { The presence of an irregular shape on US } \\
\text { and the accompaniment of suspicious } \\
\text { microcalcifications on mammography were } \\
\text { factors linked to the yielding of a lower } \\
\text { level of suspicion in the ABUS compared to } \\
\text { the HHUS regarding the assessment of } \\
\text { BI-RADS category. }\end{array}$ \\
\hline $\begin{array}{c}\text { Zhang et al., } 2019 \\
\text { China }\end{array}$ & $\begin{array}{l}\text { Study design = prospective study } \\
\text { Objective } \\
\text { - To investigate the diagnostic performance of } \\
\text { the automated breast ultrasound system } \\
\text { (ABUS), for women } 40 \text { years or older for } \\
\text { breast cancer, compared to mammography } \\
\text { (MG) and hand-held ultrasonography } \\
\text { (HHUS). } \\
\text { Participants = } 385 \text { women } \\
\text { Age range = between } 35-67 \text { years old (median } \\
\text { 49-year-old) } \\
\text { Variables = Mammography, Hand-held } \\
\text { ultrasonography, Breast cancer, Automated breast } \\
\text { ultrasound system }\end{array}$ & $\begin{array}{l}\text { Screening device = } \\
\quad \quad \text { ABVS with 6-14 MHz linear broadband } \\
\quad \text { transducer } \\
\text { HHUS with 14L5 (5-14 MHz) linear transducer } \\
\text { Duration = Between July } 2016 \text { and December } 2016 \\
\text { Follow up = 12 months } \\
\text { Interpreting Image = BI-RADS US lexicon }\end{array}$ & $\begin{array}{l}75 \text { cases were malignant while } 519 \text { were } \\
\text { benign or normal. } \\
\text { The sensitivity, specificity, accuracy and } \\
\text { Youden index were } 97.33 \%, 89.79 \%, 90.74 \% \\
\text { and } 0.87 \text { for HHUS; } 90.67 \%, 92.49 \%, 92.26 \% \\
\text { and } 0.83 \text { for ABUS; } 84.00 \%, 92.87 \%, 91.75 \% \\
\text { and } 0.77 \text { for MG, respectively. } \\
\text { The sensitivity index was } 97.33 \% \text { for HHUS, } \\
90.67 \% \text { for ABUS, } 84.00 \% \text { for MG; specificity index } \\
\text { was } 89.79 \% \text { for HHUS, } 92.49 \% \text { for ABUS, } 92.87 \% \\
\text { for MG; accuracy index was } 90.74 \% \text { for HHUS, } \\
92.26 \% \text { for ABUS, } 91.75 \% \text { for MG; and the Youden } \\
\text { index was } 0.87 \text { for HHUS, } 0.83 \text { for ABUS, and } 0.77 \\
\text { for MG). } \\
>\quad \text { Compared to HHUS, ABUS had a } \\
\text { significantly superior specificity ( } p=0.024) \text {. } \\
\text { HHUS had highest area under the receiver } \\
\text { operating characteristic curve at } 0.936, \\
\text { followed by ABUS at } 0.916 \text {, and MG at } \\
0.884 \text {. } \\
\text { The difference was not statistically } \\
\text { significant }(p>0.05) \text {. }\end{array}$ & $\begin{array}{l}\text { ABUS yielded an equivalent diagnostic } \\
\text { performance for breast cancer as MG and } \\
\text { HHUS, and therefore can be potentially } \\
\text { utilized as an alternative technique for the } \\
\text { diagnosis of breast cancer. }\end{array}$ \\
\hline
\end{tabular}


Table 2. Cont.

Author Study Design/Objectives/Participants

Study design $=$ Prospective study

Objectives

- To examine the diagnostic potential of the automated breast ultrasound (ABUS) system in differentiating malignant and
benign breast masses in comparison to

Niu et al, 2019 China handheld ultrasound (HHUS).

Participants $=398$ patients

Age range $=$ Between 29-64 years old, mean age 39 years

breast ultrasound system, ultrasound, Automate Imaging Reporting and Data System.

\section{Screening device $=$}

> A 6-14-MHz linear broadband transducer ABUS Duration = between February 2016 to March 2017 Follow up $=12$ montl

Interpreting Image $=$ BI-RADS US lexico
- Pathological results confirmed 599 masses in total, in 398 women.

were benign while the

remaining 103 were malignant.

between HHUS and ABUS in terms of

positive predictive value (46.46\% versus

positive predictive value (46.46\% versus $80.1 \%)$, negative predictive value $(95.67 \%$ versus $97.96 \%$ ), and specificity $(80.24 \%$

versus $77.62 \%$ )

$>\quad$ Significant differences were found in sensitivity $(82.52 \%$ versus $92.23 \%$; $p<0.01)$ and in areas under the curve $(0.81$ versus

$\quad 0.85 ; p<0.05)$ between HHUS and ABUS. was relatively greater between ABUS and the pathological results $(r=0.885)$ in comparison to between HHUS and the pathological results $(r=0.855)$. However the difference was not significant $(p>0.05)$.
In distinguishing between benign and malignant breast masses, automated breast US is better than HHUS, particularly regarding specificity.
Study design $=$ Retrospective

Objectives

- To examine the hand-held ultrasound

(HHUS) compared to the automated breast volume scanner (ABVS), based on the fifth edition of BI-RADS ultrasound

Choi et al., 2018

Participants $=1058$ wome

Age range $=$ between $17-79$ years old (mean age, A8.2 years)

Variables $=$ Mammary, Automated breast volum scanner, Hand-held ultrasound, Ultrasonography, Breast imaging reporting and data system, Breas neoplasms.
Screening device $=$

- The 15-cm-wide linear array transducer with - The HHUS examinations involved the use of ACUSON S2000 ultrasound system (or the ACUSON Sequoia 512

Duration = Between March 2012 and March 2014 Follow up $=12$ month

Interpreting Image $=$ BI-RADS US lexicon
> There was moderate to good interobserver a with the exception for associated features for BI-RADS lexicons ( $k=0.31$ and 0.36

respectively).

> Irregular shape, posterior features (combined or shadowing), and a on-circumscribed margin were individually linked to in both the ABVS and HHUS, malignancy.

$>\quad$ The existence of calcification on ABVS (odds ratio (OR), 95\% confidence interva (CI): 2.09, 1.11-3.94), and non-parallel 1.10-3.78) were individually linked to malignancy.

$>\quad$ No significant

betwenicant differences were found between HHUS and ABVS in sensitivity $80.5 \%)$, or AUC (0.90 vs. 0.88 ).
Based on the fifth BI-RADS edition, there is no statistically significant difference between ABVS and HHUS in tem diagnostic performance and interobserver variability. 
Table 2. Cont.

Author Study Design/Objectives/Participants

Study design $=$ cohort study design

- $\quad$ To assess the clinical performance of ABU in comparison to mammography ( $\mathrm{MG}$ ) cancer detection.

Zhang et al., 2018

China

\section{Participants $=1973$ patients}

Mean age $=45.4 \pm 9.7$ years

Variables = Automated breast ultrasound,

Hand-held ultrasound, Breast Imaging Reporting and Data System, Breast neoplasm
Screening device $=$

$>\quad$ ABVS with 6-14 MHz linear broadband

transducer

HHUS was performed using the GE LOGIQ9, Aixplorer system, iU22 Ultrasound System an s2000.

Hologic Selenia, GE Sengraphe DS, dan.

Duration = Between February 2016 and March 2017

Interpreting Image $=$ BI-RADS US lexicon

\section{Study design $=$ prospective study}

- To determine the diagnostic value of the automated breast volume scanning (ABVS)

Schmachtenberg et al 2017 breast magnetic resonance imaging (MRI) as . Participants $=28$ women
Age range $=$ between $26-76$ years old (mean age

Screening device $=$

$>\quad \mathrm{ABVS}$ with $-14 \mathrm{MHz}$ linear broadband

transduce $>\quad$ HHUS with 14L5 (5-14 MHz) linear transducer

Duration= Between July 2016 and December 2016 Follow up $=\mathrm{NP}$

Interpreting Image $=$ BI-RADS US lexicon
> $\quad 620(31.4 \%)$ and $1,353(68.6 \%)$ of these were classified as BI-RADS

The Kappa value and the agreement rate $(p<0.001)$ and $94.0 \%$, respectively; and ( $<0.001$ ) and $94.0 \%$, respectively; and $(p<0.001)$ and $89.2 \%$, respectively.

- In terms of consistency between the results of pathology and imaging, $78.6 \%$ of women classified as BI-RADS 4-5 using ABUS later were diagnosed as having cancer or precancerous lesions. This was $7.2 \%$ highe compared to women classified using HHUS

- The false-negative rates of HHUS and

than those of MG and were nearly identical.

HHUS detected 54 lesions, MRI detecte

72 lesions, and ABVS detected 59 lesion.

No significant difference was found between HHUS and ABVS regarding sensitivity $(100 \%$ vs. $93.3 \%)$, specificity $(89.7 \%$ vs. $87.2 \%)$, positive predictive value (78.9\% vs. $77.8 \%$ ) and negative predictive value $(100 \%$ vs. $95.2 \%)$.

> In terms of lesion localization (same quadrant), the agreement was $91.2 \%$ for MRI and HHUS, and $94.3 \%$ for MRI and ABVS.

$>$ The assessment of size of lesion was $(+/-3 \mathrm{~mm})$ correct in $80 \%$ (ABVS) and

$79.4 \%$ (HHUS) compared to MRI lesion size.

The correlation of measurement of size was than for HHUS-MRI $(r=0.82)$, with $p<0.001$ $\checkmark \quad$ A good diagnostic reliability was observed for ABUS. ABUS is thus a promising alternative in detecting breast cancer in China due to its lower dependen breast cancer in women with high-density breasts.

ABVS is a probable option to HHUS. Although ABVS has limitations in assessing the axillary lymph nodes, and is lacking in elastography or Doppler capacities, which occasionally give significant additiona information in HHUS, ABVS has the operator independence. 
Table 2. Cont.

\begin{tabular}{|c|c|c|c|c|}
\hline Author & Study Design/Objectives/Participants & Screening Method & Findings & Outcome \\
\hline $\begin{array}{l}\text { Hellgren et al., } 2016 \\
\text { Sweden }\end{array}$ & $\begin{array}{l}\text { Study design = Retrospective study } \\
\text { Objective } \\
\text { - To compare the specificity and sensitivity of } \\
\text { ABVS with the handheld breast US in } \\
\text { detecting breast cancer under the situation } \\
\text { of recall post mammography screening. } \\
\text { Participants = } 180 \text { women } \\
\text { Age range = aged between } 40-75 \text { years old (mean } \\
\text { 55.6 years) } \\
\text { Variables = Mammography, Breast, Primary } \\
\text { neoplasms, Ultrasound }\end{array}$ & $\begin{array}{l}\text { Screening device }= \\
\text { ABVS with } 14 \mathrm{MHz} \text { frequency. } \\
>\quad \text { HHUS using a linear L17-5 transducer or a } \\
\quad \text { L12-5. } \\
\text { Duration }=2 \text { months } \\
\text { Follow up }=12 \text { to } 24 \text { months } \\
\text { Interpreting Image }=\text { BI-RADS US lexicon }\end{array}$ & $\begin{array}{l}\text { Twenty-six cancers were discovered in } \\
25 \text { women. } \\
\text { Both ABVS and handheld US, used for } \\
\text { suspicious mammographic finding in } \\
\text { breasts }(n=118) \text {, yielded the sensitivity of } \\
88 \%(22 / 25) \text {. The specificity of the } \\
\text { handheld US was } 93.5 \%(87 / 93) \text { while it } \\
\text { was } 89.2 \%(83 / 93) \text { for the ABVS. } \\
\text { ABVS and the handheld US, used in breasts } \\
\text { with negative mammography }(n 1 / 4103), \\
\text { yielded the sensitivity of } 100 \%(1 / 1) \\
\text { The specificity of the ABVS was } 94.1 \% \\
(96 / 102) \text { while the specificity was } 100 \% \\
(102 / 102) \text { for the handheld US. }\end{array}$ & $\begin{array}{l}\text { The ABVS has the potential to replace the } \\
\text { handheld US for the investigation of } \\
\text { women recalled from mammography } \\
\text { screening due to dubious mammographic } \\
\text { findings. }\end{array}$ \\
\hline $\begin{array}{c}\text { Kim et al., } 2016 \\
\text { Korea }\end{array}$ & $\begin{array}{l}\text { Study design = prospective study } \\
\text { Objective } \\
\text { - To compare the diagnostic performance of } \\
\text { the automated breast volume scanner } \\
\text { (ABVS) and the handheld ultrasound (US) } \\
\text { as a second-look US techniques subsequent } \\
\text { to preoperative breast magnetic resonance } \\
\text { imaging (MRI) } \\
\text { Participants = 40 women } \\
\text { Age range = NP } \\
\text { Variables = Breast cancer, Breast ultrasound, } \\
\text { Second look ultrasound, Magnetic resonance } \\
\text { imaging. }\end{array}$ & $\begin{array}{l}\text { Screening device = } \\
\quad \text { MRI scan. } \\
\quad \text { ABVS imaging that was performed contained a } \\
\quad \text { 5-14-MHz wide-aperture linear transducer. } \\
\quad \text { HHUS with 7-15-MHz and 6-14-MHz linear } \\
\text { array transducers. } \\
\text { Duration = Between } 1 \text { March 2014, and } 30 \text { September } \\
2014 \\
\text { Follow up = } 12 \text { months } \\
\text { Interpreting Image = BI-RADS US lexicon }\end{array}$ & $\begin{array}{l}\text { For the second-look examination, the ABVS } \\
\text { has a higher detection rate compared to the } \\
\text { handheld US ( } 94.7 \% \text { vs. } 86.8 \% ; p<0.05) \text {. } \\
\text { Out of } 76 \text { lesions in total, only } 1 \text { was } \\
\text { discovered by the handheld US, only } 7 \text { were } \\
\text { identified by the ABVS, while neither the } \\
\text { handheld US nor the ABVS could detect the } \\
3 \text { lesions. } \\
\text { Both the handheld US and the ABVS had a } \\
\text { lower ability in detecting non-mass lesions } \\
\text { compared to the ability in detecting } \\
\text { mass-type lesions }(p<0.05) \text {. }\end{array}$ & $\begin{array}{l}\text { As a method for pre-operational assessment } \\
\text { of breast cancer patients, ABVS has a higher } \\
\text { efficiency compared to handheld US for a } \\
\text { second-look US examination subsequent to } \\
\text { preoperative breast MRI. } \\
\text { In non-mass lesion detection, both } \\
\text { techniques have limitations. }\end{array}$ \\
\hline $\begin{array}{l}\text { Jeh et al., } 2015 \\
\text { Korea }\end{array}$ & $\begin{array}{l}\text { Study design = Prospective study } \\
\text { Objective } \\
\text { - To compare the clinical utility of HHUS and } \\
\text { ABUS in breast lesion diagnosis and } \\
\text { detection. } \\
\text { Participants = } 173 \text { women } \\
\text { Age range = between } 20-80 \text { years old (mean age, } \\
48 \text { years) } \\
\text { Variables = Mammary, Ultrasonography, Early } \\
\text { detection of cancer, Breast, Diagnosis. }\end{array}$ & $\begin{array}{l}\text { Screening device = } \\
>\quad \text { ABVS with a } 5-14 \mathrm{MHz} \text { wide-aperture linear } \\
\quad \text { probe. } \\
\quad \text { HHUS using a } 7-15 \mathrm{MHz} \text { and a 6-14 MHz linear } \\
\text { transducer. } \\
\text { Duration = Between March and August } 2012 \\
\text { Follow up = NP } \\
\text { Interpreting Image = BI-RADS US lexicon }\end{array}$ & $\begin{array}{l}\text { ABUS overall detection rate was } 83.0 \% \text { while } \\
\text { HHUS overall detection rate was } 94.2 \% \text {. } \\
\text { Ten lesions, of which were } \\
\text { microcalcifications (nine benign lesions and } \\
\text { one malignant), could neither be detected } \\
\text { by ABUS nor HHUS. } \\
\text { Out of } 194 \text { lesions detected by HHUS, } \\
\text { ABUS detected } 169 \text { while the other } 25 \\
\text { benign lesions were left undetected. ABUS } \\
\text { could less frequently detect smaller-sized } \\
\text { lesions, including those of lower } \\
\text { final-assessment category and benign } \\
\text { appearance ( } p<0.0001 \text { and } p=0.011, \\
\text { respectively). }\end{array}$ & $\begin{array}{l}\text { The detection of all malignant lesions by } \\
\text { HHUS were similarly made by ABUS. } \\
\text { ABUS failed to detect a few smaller benign } \\
\text { lesions. }\end{array}$ \\
\hline
\end{tabular}


Table 2. Cont.

\begin{tabular}{|c|c|c|c|c|}
\hline Author & Study Design/Objectives/Participants & Screening Method & Findings & Outcome \\
\hline $\begin{array}{c}\text { Choi et al., } 2014 \\
\text { Korea }\end{array}$ & $\begin{array}{l}\text { Study design = Retrospective study } \\
\text { Objective } \\
\text { To examine whether the estimation of cancer } \\
\text { detection is influenced by different ultrasound } \\
\text { systems. } \\
\text { Participants }=1866 \text { ABVS and } 3700 \text { HHUS } \\
\text { participants } \\
\text { Age range }=\text { between } 19-82 \text { years old, } \\
\text { mean age } \pm \text { SD: } 47 \pm 9 \text { years } \\
\text { Variables }=\text { Screening, Breast cancer, ultrasound, } \\
\text { Automated breast volume scanning }\end{array}$ & $\begin{array}{l}\text { Screening device = } \\
\text { ABVS with 5-14 MHz with a } 9 \mathrm{MHz} \text { centre } \\
\text { frequency. } \\
\text { HHUS with a bandwidth of 5-12 MHz and a } \\
\text { linear array transducer. } \\
\text { Duration = Between September } 2010 \text { to August } 2011 \\
\text { Follow up = } 6 \text { months to } 1 \text { year } \\
\text { Interpreting Image = BI-RADS US lexicon }\end{array}$ & $\begin{array}{l}\text { ABVS had a recall rate of } 2.57 \text { per } 1000 \\
(48 / 1866) \text { while HHUS was } 3.57 \text { per } 1000 \\
(132 / 3700), \text { with a substantial difference } \\
(p=0.048) \text {. } \\
\text { Cancer detection yield was } 3.8 \text { per } 1000 \text { for } \\
\text { ABVS, and } 2.7 \text { per } 1000 \text { for HHUS. } \\
\text { The diagnostic accuracy, with a statistical } \\
\text { significance of }(p=0.018), \text { was } 96.5 \% \text { for } \\
\text { HHUS and } 97.7 \% \text { for ABVS. } \\
\text { The specificity of HHUS and ABVS were } \\
96.7 \% \text { and } 97.8 \% \text {, respectively }(p=0.022) .\end{array}$ & $\begin{array}{l}\checkmark \quad \text { The performance of ABVS is as good as } \\
\text { HHUS in detecting lesions. } \\
\text { ABVS could lead to greater anxiety for the } \\
\text { women due to more follow-ups since it has } \\
\text { a lower positive predictive value and } \\
\text { higher recall rate. } \\
\text { If given the option, over } 50 \% \text { of the women } \\
\text { would prefer HHUS. }\end{array}$ \\
\hline $\begin{array}{c}\text { Kim et al., } 2013 \\
\text { Korea }\end{array}$ & $\begin{array}{l}\text { Study design = Retrospective study } \\
\text { Objectives } \\
\text { - To compare between the automated whole } \\
\text { breast ultrasound (AWUS) and the } \\
\text { hand-held breast ultrasound (HHUS) in } \\
\text { terms of their detection performance. } \\
\text { To evaluate the variability of interobserver } \\
\text { in interpreting AWUS. } \\
\text { Participants = 45 women } \\
\text { Age range = NP } \\
\text { Variables = Observer variation, Ultrasonography, } \\
\text { Breast }\end{array}$ & $\begin{array}{l}\text { Screening device = } \\
\text { Mammograms. } \\
\text { ABVS with a 5-14 MHz frequency. } \\
\quad \quad \text { HHUS using a 7-15 MHz linear probe and a } \\
\quad 6-14 \text { MHz linear probe. } \\
\text { Duration= From October of } 2009 \text { to March of } 2010 \\
\text { Follow up = NP } \\
\text { Interpreting Image = BI-RADS US lexicon }\end{array}$ & $\begin{array}{l}\text { The malignancy detection rate for HHUS } \\
\text { was } 98.0 \% \text {, while that of the three readers } \\
\text { for AWUS were } 90.0 \%, 88.0 \% \text { and } 96.0 \% \text {. } \\
\text { In HHUS, the specificity and sensitivity } \\
\text { were } 62.5 \% \text { and } 98.0 \%, 90.0 \% \text { and } 87.5 \% \text { for } \\
\text { reader } 1,88.0 \% \text { and } 81.3 \% \text { for reader } 2, \text { and } \\
96.0 \% \text { and } 93.8 \% \text { for reader } 3 \text {, in AWUS } \\
>\quad \text { No significant difference was found in the } \\
\text { sensitivity, specificity, and detection } \\
\text { performance of the radiologists }(p>0.05) \\
\text { between the two modalities. } \\
\text { Fair to good interobserver agreement was } \\
\text { found for size, location of breast masses, } \\
\text { ultrasonographic features, and } \\
\text { categorization. }\end{array}$ & $\begin{array}{l}\text { AWUS is assumed as beneficial for breast } \\
\text { lesion detection. } \\
\text { There is no significant difference between } \\
\text { HHUS and AWUS in terms of specificity, } \\
\text { detection rate, and sensitivity. However, } \\
\text { AWUS demonstrated high degree of } \\
\text { interobserver agreement. }\end{array}$ \\
\hline $\begin{array}{c}\text { Chen et al., } 2013 \\
\text { China }\end{array}$ & $\begin{array}{l}\text { Study design = Retrospective study } \\
\text { Objective } \\
\text { - To clarify ABVS value compared to HHUS } \\
\text { in the differentiation of malignant and } \\
\text { benign breast masses } \\
\text { Participants = } 182 \text { women } \\
\text { Age range = Between } 16-71 \text { years old; mean age, } \\
\text { 11.7 years } \\
\text { Variables = Automated breast volume scanner, } \\
\text { Ultrasonography, and Breast cancer. }\end{array}$ & $\begin{array}{l}\text { Screening device = } \\
>\quad \text { ABVS with integrated }(15.4 \mathrm{~cm}) 14 \mathrm{~L} 5 \mathrm{BV} \text { linear } \\
\quad \text { transducer } \\
\quad \text { HHUS with 9L4 }(4-9 \mathrm{MHz}) \text { or } 14 \mathrm{~L} 5(5-14 \mathrm{MHz}) \\
\text { linear transducers. } \\
\text { Duration = September } 2010 \text { and April } 2012 \\
\text { Follow up = NP } \\
\text { Interpreting Image = BI-RADS US lexicon }\end{array}$ & $\begin{array}{l}\text { No differences were shown between the } \\
\text { ABVS and HHUS regarding accuracy } \\
(88.1 \% \text { vs. } 87.2 \%), \text { specificity }(86.2 \% \text { vs. } \\
87.5 \%) \text {, sensitivity ( } 92.5 \% \text { vs. } 88.0 \%), \\
\text { false-positive rate }(13.8 \% \text { vs. } 12.5 \%), \\
\text { false-negative rate }(11.8 \% \text { vs. } 7.5 \%), \\
\text { negative predictive value }(96.3 \% \text { vs. } 94.3 \%), \\
\text { and positive predictive value }(74.7 \% \text { vs. } \\
75.6 \%)(p=0.05 \text { for all). }\end{array}$ & $\begin{array}{l}\text { There is no difference in diagnostic } \\
\text { accuracy between HHUS and ABVS in } \\
\text { discriminating malignant or benign breast } \\
\text { masses. }\end{array}$ \\
\hline
\end{tabular}


Table 2. Cont.

\begin{tabular}{|c|c|c|c|c|}
\hline Author & Study Design/Objectives/Participants & Screening Method & Findings & Outcome \\
\hline $\begin{array}{l}\text { Lin et al., } 2012 \\
\quad \text { China }\end{array}$ & $\begin{array}{l}\text { Study design = Prospective study } \\
\text { Objective } \\
\text { - To examine the clinical utility of automated } \\
\text { breast volume scanner (ABVS) compared to } \\
\text { the handheld ultrasound for detecting and } \\
\text { providing diagnosis of breast lesions. } \\
\text { Participants = } 81 \text { women } \\
\text { Age range = between } 16-78 \text { years old; mean } \\
\text { 40.7 years } \\
\text { Variables = Automated, Ultrasonography, Breast } \\
\text { lesion, Diagnostic imaging }\end{array}$ & $\begin{array}{l}\text { Screening device = } \\
\quad \text { ABVS with a wide aperture 14L5BV linear array } \\
\text { transducer and central frequency of transducer } \\
\text { varied from } 9 \text { to } 11 \mathrm{MHz} \text {. } \\
\text { HHUS that uses the } 18 \mathrm{~L} 6 \mathrm{HD} \text { linear array } \\
\text { transducer at } 10 \mathrm{MHz} \text { grayscale central } \\
\text { frequency. } \\
\text { Duration }=1 \text { month } \\
\text { Follow up }=12 \text { months } \\
\text { Interpreting Image = BI-RADS US lexicon }\end{array}$ & $\begin{array}{l}\text { 95 breast lesions were detected by both } \\
\text { automated breast volume scanner and } \\
\text { handheld ultrasound. } \\
\text { Both handheld ultrasound and ABVS } \\
\text { demonstrated high specificity }(85.0 \% \text {, and } \\
95.0 \% \text { respectively), and high sensitivity } \\
\text { (both } 100 \%) \text {. } \\
\text { For breast neoplasms, a higher diagnostic } \\
\text { accuracy was demonstrated by handheld } \\
\text { ultrasound }(91.4 \%) \text { than ABVS }(97.1 \%) \text {. } \\
\text { No significant difference was demonstrated } \\
\text { in maximum diameters of 2D, ABVS, and } \\
\text { pathology }(p>0.05) . \\
\text { There was better correlation with pathology } \\
(\mathrm{r}=0.616) \text { than } 2 \mathrm{D}(\mathrm{r}=0.468) \text { for ABVS. }\end{array}$ & $\begin{array}{l}\text { The automated breast volume scanner is a } \\
\text { promising modality in breast imaging with } \\
\text { the benefits of operator-independence, high } \\
\text { diagnostic accuracy, whole-breast } \\
\text { visualization, and greater prediction of } \\
\text { lesion size. }\end{array}$ \\
\hline $\begin{array}{c}\text { Wang et al., } 2012 \\
\text { China }\end{array}$ & $\begin{array}{l}\text { Study design = prospective study } \\
\text { Objective } \\
\text { - To assess the diagnostic value for the } \\
\text { discrimination of breast lesions that are } \\
\text { benign and malignant, between the } \\
\text { automated breast volume scanning (ABVS) } \\
\text { and the conventional handheld } \\
\text { ultrasonography (HHUS). } \\
\text { Participants = } 213 \text { women } \\
\text { Age range = aged between 11-81 years, average } \\
43.0 \pm 12.5 \text { years } \\
\text { Variables = Breast sonography, Automated breast } \\
\text { volume scanner, Breast lesions, 3D imaging }\end{array}$ & $\begin{array}{l}\text { Screening device }= \\
\quad \quad \text { ABVS with frequency of } 5-14 \mathrm{MHz} \text { transducer } \\
\quad(15.4 \mathrm{~cm}) . \\
\quad \quad \text { HHUS with } 18 \mathrm{~L} 6 \text { linear transducer. } \\
\text { Duration= Between August } 2010 \text { and December } 2010 \\
\text { Follow up = NP } \\
\text { Interpreting Image = BI-RADS US lexicon }\end{array}$ & $\begin{array}{l}\text { The pathology of } 239 \text { breast lesions } \\
\text { revealed that } 154(64.4 \%) \text { were benign and } \\
85(35.6 \%) \text { were malignant lesions. } \\
\text { There are similarities between ABVS and } \\
\text { HHUS regarding specificitit }(80.5 \% \text { vs. } \\
82.5 \%) \text { sensitivity }(95.3 \% \text { vs. } 90.6 \%), \\
\text { accuracy }(85.8 \% \text { vs. } 85.3 \%), \text { positive } \\
\text { predictive value }(73.0 \% \text { vs. } 74.0 \%) \text {, and } \\
\text { negative predictive value }(93.3 \% \text { vs. } 94.1 \%) \\
\text { Only minor differences were demonstrated } \\
\text { by the area under the receiver operating } \\
\text { characteristic (ROC) curve used to estimate } \\
\text { the accuracy between HHUS and ABVS } \\
(0.928 \text { and } 0.948, \text { respectively). }\end{array}$ & $\begin{array}{l}\text { In the differentiation of breast lesions that } \\
\text { are malignant and benign, HHUS and } \\
\text { ABVS had almost identical diagnostic } \\
\text { accuracy. } \\
\text { ABVS may assist in uncovering small } \\
\text { lesions, demonstrating the presence of } \\
\text { intraductal lesions, and distinguishing } \\
\text { between real lesions and inhomogeneous } \\
\text { areas. } \\
\text { This technique is feasible for clinical } \\
\text { application and is a promising new } \\
\text { modality in breast imaging. }\end{array}$ \\
\hline $\begin{array}{c}\text { Wojcinski et al., } 2011 \\
\text { Germany }\end{array}$ & $\begin{array}{l}\text { Study design = Cohort study design } \\
\text { Objective } \\
\text { - To assess the detectability of breast lesions } \\
\text { by independent examiner using only ABVS } \\
\text { data of breast lesions that were previously } \\
\text { detected using conventional ultrasound. }\end{array}$ & $\begin{array}{l}\text { Screening device = } \\
\quad \quad \text { ABVS with } 14 \mathrm{~L} 5 \mathrm{BV} \text { linear transducer }(14 \mathrm{MHz}, \\
\quad 15.4 \mathrm{~cm}) . \\
\quad \text { HHUS using } 18 \mathrm{~L} 6 \mathrm{HD} \text { linear transducer } \\
\quad(5.5-18 \mathrm{MHz}) . \\
\text { Duration = Between March } 2010 \text { and May } 2010 \\
\text { Follow up = NP } \\
\text { Interpreting Image = BI-RADS US lexicon }\end{array}$ & $\begin{array}{l}\text { The experimental ABVS yielded a } \\
\text { sensitivity of } 100 \% \text { in the described setting } \\
\text { (95\% CI: } 73.2-100 \%) \text {, and } 66.0 \% \text { diagnostic } \\
\text { accuracy }(95 \% \text { confidence interval (CI: } \\
52.9-79.1) \text {. } \\
\text { The specificity was maintained at } 52.8 \% \\
\text { (95\% CI: } 35.7-69.2) \text {. } \\
\text { Comparison between the ABVS } \\
\text { concordance with the gold standard } \\
\text { (conventional handheld ultrasound) } \\
\text { indicated a fair agreement between both, } \\
\text { with the value of Cohen Kappa as an } \\
\text { estimation of the inter-rater reliability of } \\
\mathrm{k}=0.37 \text {. }\end{array}$ & $\begin{array}{l}\text { For breast ultrasound, ABVS must continue } \\
\text { to be perceived as an experimental } \\
\text { technique, thus requiring further evaluation } \\
\text { studies. }\end{array}$ \\
\hline
\end{tabular}


Table 2. Cont.

\begin{tabular}{|c|c|c|c|c|}
\hline Author & Study Design/Objectives/Participants & Screening Method & Findings & Outcome \\
\hline $\begin{array}{l}\text { Chang et al., } 2011 \\
\text { Korea }\end{array}$ & $\begin{array}{l}\text { Study design }=\text { Retrospective study } \\
\text { Objective } \\
\text { - To examine, retrospectively the detection } \\
\text { performance of malignant and benign breast } \\
\text { masses with the utilization of } 3 \mathrm{D} \text { volume } \\
\text { data obtained by ABUS, and to determine } \\
\text { the variables of lesion that influence } \\
\text { detectability } \\
\text { Participants }=67 \text { women } \\
\text { Age range = Between } 20-79 \text { years old, mean age, } \\
47 \pm 14 \text { years } \\
\text { Variables = Detection performance, Screen US, } \\
\text { Hand-held ultrasound, Automated breast US. }\end{array}$ & $\begin{array}{l}\text { Screening device = } \\
\quad \text { ABVS with } 7.5-10 \mathrm{MHz} \text { transducer. } \\
\quad \text { HHUS with 6-14 MHz linear transducer. } \\
\text { Duration= Between November to December of } 2007 \\
\text { Follow up = minimum } 30 \text { months } \\
\text { Interpreting Image = BI-RADS US lexicon }\end{array}$ & $\begin{array}{l}\text { The sensitivities for the detection of benign } \\
\text { and malignant masses were } 65.2 \%(30 / 46), \\
95.8 \%(23 / 24) \text { for reader } 1(p=0.007), 66.7 \% \\
(31 / 46), 87.5 \%(21 / 24) \text { for reader } 2 \\
(p=0.087), \text { and } 56.3 \%(24 / 46), 91.7 \% \\
(22 / 24) \text { for reader } 3(p=0.001), \text { respectively. } \\
\text { It is demonstrated in the logistic analysis } \\
\text { that mass shape (odds ratio, } 95 \% \text { CI; } 3.12, \\
1.02-9.55) \text {, size of the mass (odds ratio, } 95 \% \\
\text { CI; } 1.12,1.02-1.24) \text {, and changes in } \\
\text { surrounding tissue (odds ratio, } 95 \% \text { CI; } 0.11 \text {, } \\
\text { 0.02-0.47) were the variables linked to the } \\
\text { ABUS detectability. }\end{array}$ & $\begin{array}{l}\text { Significantly higher sensitivity was } \\
\text { demonstrated in reader studies using ABUS } \\
\text { data for breast masses that are malignant } \\
\text { than benign. }\end{array}$ \\
\hline $\begin{array}{c}\text { Shin et al., } 2011 \\
\text { Korea }\end{array}$ & $\begin{array}{l}\text { Study design }=\text { Prospective study } \\
\text { Objective } \\
\text { - To evaluate, prospectively, the interobserver } \\
\text { agreement of five radiologists in detecting } \\
\text { lesions, and the characterization in the } \\
\text { review of automated ultrasound breast } \\
\text { images. } \\
\text { Participants }=55 \text { women } \\
\text { Age range = aged between } 29-69 \text { years; mean } \\
48 \text { years } \\
\text { Variables = Automated ultrasound, Breast, } \\
\text { Neoplasm }\end{array}$ & $\begin{array}{l}\text { Screening device = } \\
\quad \quad \text { ABVS using a 5-14 MHz with a 9-MHz centre } \\
\text { frequency. } \\
\text { HHUS using a linear 5-12 MHz transducer. } \\
\text { Duration = From August to October } 2009 \\
\text { Follow up = NP } \\
\text { Interpreting Image = BI-RADS US lexicon }\end{array}$ & 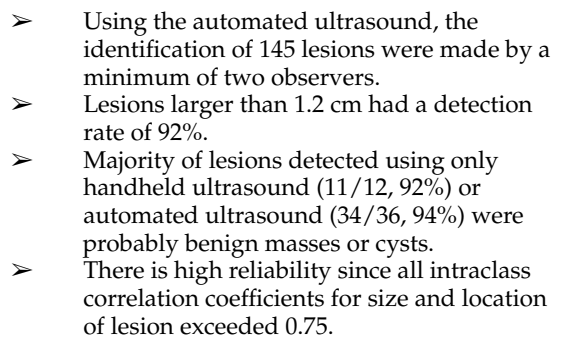 & $\begin{array}{l}\text { The reporting of lesion location and size } \\
\text { yielded high reliability. } \\
\text { The description of key features and final } \\
\text { assessment category demonstrated } \\
\text { substantial agreement. }\end{array}$ \\
\hline
\end{tabular}


Jeh et al. reported the BI-RADS final assessment of 124 classifications as 1,2 , and 3 while 45 malignant classifications were 4 and 5 [33]. Lin et al. identified 15 carcinomas noticed in BI-RADS classification 4-5, and 20 females with breasts in classification 1-3 [34]. Wojcinski et al. identified that 6 out of 14 lesions had been classified as BI-RADS 0, 3 or 4 while 8 out of 14 malignant lesions had been properly classified as BI-RADS 5 [26]. Of masses that were benign, 39 were categorized as BI-RADS 4 while another 7 were characterized as BI-RADS 3. Of masses that were malignant, 16 were accounted for as BI-RADS 5, while 8 masses that were malignant were categorized as BI-RADS 4 [20]. The evaluation of 145 lesions in Shin et al. marked the final evaluation of the BI-RADS classes, where 145 lesions were accounted for by five readers as category 1 or 2 (40\%, 240 of 603$), 3$ $(31 \%, 184$ of 603$), 4 \mathrm{~A}(11 \%, 68$ of 603$), 4 \mathrm{~B}(3 \%, 19$ of 603$), 4 \mathrm{C}(2 \%, 12$ of 603$)$, and 5 (13\%, 80 of 603) [35].

\subsection{Tumour Stage and Size (Lymph Node and Non-Invasive/Invasive Status)}

The detected carcinomas had a mean size of $2.1 \mathrm{~cm}$ (mean size ranged between $1.6 \mathrm{~cm}$ to $2.6 \mathrm{~cm}$ ) in seven of the 21 studies [33-39]. The mean level of malignancy detected was $94 \%(81-100 \%)$ contrasted with non-cancer in all examinations. The status of intramammary lymph node was accounted for in one analysis, with lymph nodes that were negative in all studies [31] (Table 2).

\subsection{Assessment Categories for Breast Ultrasound}

The positive predictive value concerning the finding of malignancies in biopsies that are prompted/detected by ultrasound was accounted for, or had the option to be derived from the information provided by eleven studies. The percentage of positivelyclassified findings for carcinoma was then found to range between $4.1-100 \%$ for both ABVS and HHUS. The large variation of these positive predictive values is chiefly due to the application of different assessment categories and different sonographic criteria for malignancy. Only three studies reported that all findings were classified as benign post biopsy $[35,39,40]$. Nonetheless, three studies did not specify the follow-up for patients with positive outcomes $[26,33,41]$ (Table 2 ).

\section{Discussion}

ABVS is a novel imaging method for automated breast scanning via ultrasound. The use of this method was first made in the screening setting to enhance the detection of breast cancer [5]. Recently, the evaluation of the use of ABVS in the diagnostic stage has been made by various studies. However, the diagnostic capability of the ABVS continues to be disputable since it is a "novel" method, especially in comparison with the traditional HHUS. It was reported in Meng et al. that ABVS demonstrated decreased specificity compared to HHUS, although both ABVS and HHUS demonstrated equal sensitivity [19]. In a metaanalysis in Zhang et al., the same detection rate (100\%) was found in both HHUS and ABVS in detecting breast cancer. However, ABVS demonstrated numerically greater specificity (86\% vs. $82 \%$ ) and sensitivity (93\% vs. $90 \%$ ) in comparison with HHUS [30]. On the other hand, Wang and Qi reported that ABVS and HHUS demonstrated similar specificity and sensitivity in discriminating benign breast lesions from malignant. The pooled values of specificity and sensitivity for ABVS were $82.2 \%$ and $90.8 \%$, respectively, while HHUS pooled specificity and sensitivity values were $81.0 \%$ and $90.6 \%$, respectively [42].

This systematic review aimed to determine the evidence available on ABVS and HHUS diagnostic accuracy in identifying malignant and benign breast lesions. Based on the data in this study, similar sensitivity and specificity were demonstrated for ABVS and HHUS in discriminating malignant and benign breast lesions. Among 14 studies, the sensitivity range was (0.72-1.0) for ABVS and (0.62-1.0) for HHUS and the specificity range was (0.52-0.98) for ABVS and (0.49-0.99) for HHUS; while among 11 studies, the accuracy range was (59-98)\% and (80-99)\% for ABVS and HHUS, respectively. On the other hand, as suggested in the studies of Kim et al. and Wang et al., ABVS can be effectively utilized in 
detecting and characterizing breast lesions, since its sensitivity is not inferior [36,40]. As found in the study of Tutar et al., ABVS succeeded in detecting all malignant lesions, apart from the fact that no interval cancers were detected in the very long follow-up period. A greater number of benign lesions could be fundamentally identified by ABVS in comparison to HHUS. There is a possibility that a proportion of solid nodules detected using ABVS could be focal fat lobules [24].

The article review has shown that a statistically significant difference in results exists between HHUS and ABVS, since HHUS contained a larger amount of BI-RADS 1-2 compared to BI-RADS 0 or 4 discovered in ABVS. This indicates the probability of ABVS resulting in better clinical practice regarding biopsies, follow-ups, and recalls, in comparison to HHUS.

Based on the outcomes of Yun et al. it is confirmed that a relationship exists between ABVS allocation of a lower BI-RADS category and HHUS allocation of US results of irregular shape [25].

Posterior shadowing is a notable limitation of ABVS, identified by the recall or falsenegative rate. Notwithstanding the findings for lesion size, no association was revealed in our study group between orientation, margin, or posterior acoustic features and a lower categorization utilizing ABUS. It was shown in the study results of Zhang et al. that the ABVS findings were in greater sync with the pathological outcomes of the BI-RADS 4-5 groups [32]. The 78.6\% of females diagnosed with cancer or precancerous lesions, from those classified by ABVS as BI-RADS 4 or 5 , was $7.2 \%$ greater compared to the female proportion in a similar group of BI-RADS classification based on HHUS. However, the false-negative rates of the BI-RADS 1-2 groups for both ABVS and HHUS were not distinguishable from each other.

On the other hand, emphasis should be made on the fact that HHUS and ABVS diagnostic performance similarity is largely dependent on the interpretation of the Grayscale ultrasound. No clear statement on the usage of elastography and Doppler ultrasound in HHUS was made in any of the 21 studies included. This suggests that, for breast lesion differential diagnosis, no additional information on vascularity and elasticity was provided, when only the morphological features on Gray-scale images for HHUS and ABVS were used. Breast ultrasound diagnostic accuracy could therefore be significantly improved due to the ability of both elastography and Doppler ultrasound to provide independent diagnostic information apart from Gray-scale imaging. Nevertheless, the investigation of tissue elasticity and lesion vascularity continues currently to be performed by ABVS in the clinical environment. Henceforth, the diagnostic performance of HHUS in the involved studies may be underestimated relative to the clinical reality. Therefore, there is a probability of an underestimation of HHUS diagnostic performance made in the involved studies in relation to clinical reality.

However, a great advantage of ABVS in breast lesion characterization in comparison to HHUS is its capability in obtaining additional data on the reconstructed coronal plane's morphological features. In the differentiation of breast lesions that are malignant and benign, the ABVS coronal plane retraction phenomenon is perceived as having high probability as a diagnostic feature (Depretto et al., 2020; Jia et al., 2020; Tutar et al., 2020; Yun et al., 2019; Zhang et al., 2019; Niu et al., 2019; Choi et al., 2018; Zhang et al., 2018; Schmachtenberg et al., 2017; Hellgren et al., 2017; Jeh et al., 2015; Choi et al., 2014; Chen et al., 2013; Kim et al., 2013; Lin et al., 2012; Wang et al., 2012; Wojcinski et al., 2011; Chang et al., 2011; Shin et al., 2011). Thus, it can be sensibly concluded that in terms of differential findings assisted by coronal reconstruction, ABVS might be better when compared to HHUS.

Nonetheless, the reviewed article demonstrates that the diagnostic performance of ABVS is similar to the diagnostic performance of HHUS. In terms of benign and malignant breast lesion differential diagnosis, no confirmation was made in our study regarding the added benefit of using ABVS for coronal reconstruction. The results of Zhang et al. are in agreement with those of our study which indicated that, regarding AUC values, ABVS 
diagnostic performance might not be significantly improved through coronal reconstruction [30]. In the study of Zhang et al., a suggestion was made that ABVS independent value limitation in the differential diagnosis is caused by the low sensitivity $(37.0 \%)$ of the retraction phenomenon on the coronal plane [32]. The limitations in our study include the substantial dominance of Asian reports, with 15 out of 21.

Variations might have occurred due to the uneven geographic distribution since there are breast cancer differences regarding region and ethnicity between non-Asian and Asian women. Besides, no indication was made in any of the studies included regarding an image quality control statement, which should thus be noted as a variable that is unaccounted for, both for ABVS and HHUS. Third, based on our references, no investigation has made use of Doppler and elastography ultrasound in HHUS, in contrast to the practice in clinical reality. Finally, publication bias might have been prompted since evaluation was made only of articles written in English. Therefore, our reviewed articles may have underestimated the diagnostic performance of HHUS.

\section{Conclusions}

In relation to malignant and benign breast lesion differentiation, ABVS diagnostic performance based on the evidence available in the literature is similar to that of HHUS. However, ABVS can offer new diagnostic information. ABVS may help to distinguish between real lesions. This technique is feasible for clinical applications and is a promising modality in breast imaging. Nevertheless, since this review of articles was conducted on various studies, most of which were obtained from a single geographical region, further studies are hence required before the generalization of this conclusion can be made. More sound research associating the diagnostic performance of ABVS and mammography/MRI is anticipated and required.

Author Contributions: Conceptualization, S.A.I., R.M., S.M.S. and H.A.H.; methodology, S.A.I. and A.M.D.; software, S.A.I.; validation, S.A.I. and A.S.K.; formal analysis, S.A.I. and A.M.D.; investigation, S.A.I. and A.S.K.; resources, S.A.I.; data curation, S.A.I.; writing—original draft, S.A.I.; writing—review and editing, S.A.I., R.M., S.M.S., H.A.H., A.S.K. and A.M.D.; visualization, S.A.I., R.M., S.M.S., H.A.H., A.S.K. and A.M.D.; supervision, R.M., S.M.S. and H.A.H.; project administration, S.A.I.; funding acquisition, S.M.S. All authors have read and agreed to the published version of the manuscript.

Funding: No funding was received for this review.

Institutional Review Board Statement: Not applicable.

Informed Consent Statement: Not applicable.

Data Availability Statement: Data is available from the studies included in the review that have been cited.

Conflicts of Interest: The authors declare no conflict of interest.

\section{References}

1. Siegel, R.L.; Miller, K.D.; Jemal, A. Cancer statistics, 2020. CA Cancer J. Clin. 2020, 70, 7-30. [CrossRef] [PubMed]

2. Azizah, A.M.; Hashimah, B.; Nirmal, K.; Siti Zubaidah, A.R.; Puteri, N.A.; Nabihah, A.; Sukumaran, R.; Balqis, B.; Nadia, S.M.R.; Sharifah, S.S.S.; et al. Malaysian National Cancer Registry Report 2012-2016. Malaysia Cancer Statistics, Data and Figure; National Cancer Institute, Ministry of Health: Putrajaya, Malaysia, 2019.

3. Van den Ende, C.; Oordt-Speets, A.M.; Vroling, H.; van Agt, H.M. Benefits and harms of breast cancer screening with mammography in women aged 40-49 years: A systematic review. Int. J. Cancer 2017, 141, 1295-1306. [CrossRef] [PubMed]

4. Partridge, A.H.; Pagani, O.; Abulkhair, O.; Aebi, S.; Amant, F.; Azim, H.A., Jr.; Harbeck, N. First international consensus guidelines for breast cancer in young women (BCY1). Breast 2014, 23, 209-220. [CrossRef] [PubMed]

5. Brem, R.F.; Lenihan, M.J.; Lieberman, J.; Torrente, J. Screening breast ultrasound: Past, present, and future. Am. J. Roentgenol. 2015, 204, 234-240. [CrossRef] [PubMed]

6. Burkett, B.J.; Hanemann, C.W. A review of supplemental screening ultrasound for breast cancer: Certain populations of women with dense breast tissue may benefit. Acad. Radiol. 2016, 23, 1604-1609. [CrossRef]

7. Rebolj, M.; Assi, V.; Brentnall, A.; Parmar, D.; Duffy, S.W. Addition of ultrasound to mammography in the case of dense breast tissue: Systematic review and meta-analysis. Br. J. Cancer 2018, 118, 1559-1570. [CrossRef] 
8. Kaplan, S.S. Automated whole breast ultrasound. Radiol. Clin. 2014, 52, 539-546. [CrossRef]

9. Van Zelst, J.C.; Mann, R.M. Automated three-dimensional breast US for screening: Technique, artifacts, and lesion characterization. Radiographics 2018, 38, 663-683. [CrossRef]

10. Xiao, Y.M.; Chen, Z.H.; Zhou, Q.C.; Wang, Z. The efficacy of automated breast volume scanning over conventional ultrasonography among patients with breast lesions. Int. J. Gynecol. Obstet. 2015, 131, 293-296. [CrossRef]

11. Kotsianos-Hermle, D.; Wirth, S.; Fischer, T.; Hiltawsky, K.M.; Reiser, M. First clinical use of a standardized three-dimensional ultrasound for breast imaging. Eur. J. Radiol. 2009, 71, 102-108. [CrossRef]

12. Rella, R.; Belli, P.; Giuliani, M.; Bufi, E.; Carlino, G.; Rinaldi, P.; Manfredi, R. Automated breast ultrasonography (ABUS) in the screening and diagnostic setting: Indications and practical use. Acad. Radiol. 2018, 25, 1457-1470. [CrossRef] [PubMed]

13. Shin, H.J.; Kim, H.H.; Cha, J.H. Current status of automated breast ultrasonography. Ultrasonography 2015, 34, 165. [CrossRef] [PubMed]

14. Grady, I.; Chanisheva, N.; Vasquez, T. The addition of automated breast ultrasound to mammography in breast cancer screening decreases stage at diagnosis. Acad. Radiol. 2017, 24, 1570-1574. [CrossRef]

15. Wang, X.L.; Tao, L.; Zhou, X.L.; Wei, H.; Sun, J.W. Initial experience of automated breast volume scanning (ABVS) and ultrasound elastography in predicting breast cancer subtypes and staging. Breast 2016, 30, 130-135. [CrossRef] [PubMed]

16. Xu, C.; Wei, S.; Xie, Y.; Guan, X.; Fu, N.; Huang, P.; Yang, B. Combined use of the automated breast volume scanner and the US elastography for the differentiation of benign from malignant lesions of the breast. BMC Cancer 2014, 14, 798. [CrossRef] [PubMed]

17. Zheng, F.Y.; Yan, L.X.; Huang, B.J.; Xia, H.S.; Wang, X.; Lu, Q.; Wang, W.P. Comparison of retraction phenomenon and BI-RADS-US descriptors in differentiating benign and malignant breast masses using an automated breast volume scanner. Eur. J. Radiol. 2015, 84, 2123-2129. [CrossRef] [PubMed]

18. Wojcinski, S.; Gyapong, S.; Farrokh, A.; Soergel, P.; Hillemanns, P.; Degenhardt, F. Diagnostic performance and inter-observer concordance in lesion detection with the automated breast volume scanner (ABVS). BMC Med. Imaging 2013, 13, 36. [CrossRef]

19. Meng, Z.; Chen, C.; Zhu, Y.; Zhang, S.; Wei, C.; Hu, B.; Shen, E. Diagnostic performance of the automated breast volume scanner: A systematic review of inter-rater reliability/agreement and meta-analysis of diagnostic accuracy for differentiating benign and malignant breast lesions. Eur. Radiol. 2015, 25, 3638-3647. [CrossRef]

20. Chang, J.M.; Moon, W.K.; Cho, N.; Park, J.S.; Kim, S.J. Radiologists' performance in the detection of benign and malignant masses with 3D automated breast ultrasound (ABUS). Eur. J. Radiol. 2011, 78, 99-103. [CrossRef]

21. Moher, D.; Liberati, A.; Tetzlaff, J.; Altman, D.G.; Altman, D.; Antes, G.; Tugwell, P. Preferred reporting items for systematic reviews and meta-analyses: The PRISMA statement (Chinese edition). J. Chin. Integr. Med. 2009, 7, 889-896. [CrossRef]

22. Whiting, P.F.; Rutjes, A.W.; Westwood, M.E.; Mallett, S.; Deeks, J.J.; Reitsma, J.B.; Bossuyt, P.M. QUADAS-2: A revised tool for the quality assessment of diagnostic accuracy studies. Ann. Intern. Med. 2011, 155, 529-536. [CrossRef] [PubMed]

23. Jia, M.; Lin, X.; Zhou, X.; Yan, H.; Chen, Y.; Liu, P.; Sankaranarayanan, R. Diagnostic performance of automated breast ultrasound and handheld ultrasound in women with dense breasts. Breast Cancer Res. Treat. 2020, 181, 589-597. [CrossRef] [PubMed]

24. Tutar, B.; Icten, G.E.; Guldogan, N.; Kara, H.; Arıkan, A.E.; Tutar, O.; Uras, C. Comparison of automated versus hand-held breast US in supplemental screening in asymptomatic women with dense breasts: Is there a difference regarding woman preference, lesion detection and lesion characterization? Arch. Gynecol. Obstet. 2020, 301, 1257-1265. [CrossRef]

25. Yun, G.; Kim, S.M.; La Yun, B.; Ahn, H.S.; Jang, M. Reliability of automated versus handheld breast ultrasound examinations of suspicious breast masses. Ultrasonography 2019, 38, 264. [CrossRef] [PubMed]

26. Wojcinski, S.; Farrokh, A.; Hille, U.; Wiskirchen, J.; Gyapong, S.; Soliman, A.A.; Hillemanns, P. The automated breast volume scanner (ABVS): Initial experiences in lesion detection compared with conventional handheld B-mode ultrasound: A pilot study of 50 cases. Int. J. Women's Health 2011, 3, 337. [CrossRef] [PubMed]

27. Schmachtenberg, C.; Fischer, T.; Hamm, B.; Bick, U. Diagnostic performance of automated breast volume scanning (ABVS) compared to handheld ultrasonography with breast MRI as the gold standard. Acad. Radiol. 2017, 24, 954-961. [CrossRef]

28. Depretto, C.; Liguori, A.; Primolevo, A.; Di Cosimo, S.; Cartia, F.; Ferranti, C.; Scaperrotta, G.P. Automated breast ultrasound compared to hand-held ultrasound in surveillance after breast-conserving surgery. Tumori J. 2020, 107, 132-138. [CrossRef]

29. Niu, L.; Bao, L.; Zhu, L.; Tan, Y.; Xu, X.; Shan, Y.; Shen, Y. Diagnostic performance of automated breast ultrasound in differentiating benign and malignant breast masses in asymptomatic women: A comparison study with handheld ultrasound. J. Ultrasound Med. 2019, 38, 2871-2880. [CrossRef]

30. Zhang, L.; Bao, L.Y.; Tan, Y.J.; Zhu, L.Q.; Xu, X.J.; Zhu, Q.Q.; Liu, J. Diagnostic performance using automated breast ultrasound system for breast cancer in Chinese women aged 40 years or older: A comparative study. Ultrasound Med. Biol. 2019, 45, 3137-3144. [CrossRef]

31. Choi, E.J.; Choi, H.; Park, E.H.; Song, J.S.; Youk, J.H. Evaluation of an automated breast volume scanner according to the fifth edition of BI-RADS for breast ultrasound compared with hand-held ultrasound. Eur. J. Radiol. 2018, 99, 138-145. [CrossRef]

32. Zhang, X.; Lin, X.; Tan, Y.; Zhu, Y.; Wang, H.; Feng, R.; Qiao, Y. A multicenter hospital-based diagnosis study of automated breast ultrasound system in detecting breast cancer among Chinese women. Chin. J. Cancer Res. 2018, 30, 231. [CrossRef] [PubMed]

33. Jeh, S.K.; Kim, S.H.; Choi, J.J.; Jung, S.S.; Choe, B.J.; Park, S.; Park, M.S. Comparison of automated breast ultrasonography to handheld ultrasonography in detecting and diagnosing breast lesions. Acta Radiol. 2016, 57, 162-169. [CrossRef] [PubMed] 
34. Lin, X.; Wang, J.; Han, F.; Fu, J.; Li, A. Analysis of eighty-one cases with breast lesions using automated breast volume scanner and comparison with handheld ultrasound. Eur. J. Radiol. 2012, 81, 873-878. [CrossRef] [PubMed]

35. Shin, H.J.; Kim, H.H.; Cha, J.H.; Park, J.H.; Lee, K.E.; Kim, J.H. Automated ultrasound of the breast for diagnosis: Interobserver agreement on lesion detection and characterization. Am. J. Roentgenol. 2011, 197, 747-754. [CrossRef] [PubMed]

36. Wang, H.Y.; Jiang, Y.X.; Zhu, Q.L.; Zhang, J.; Dai, Q.; Liu, H.; Sun, Q. Differentiation of benign and malignant breast lesions: A comparison between automatically generated breast volume scans and handheld ultrasound examinations. Eur. J. Radiol. 2012, 81, 3190-3200. [CrossRef]

37. Choi, W.J.; Cha, J.H.; Kim, H.H.; Shin, H.J.; Kim, H.; Chae, E.Y.; Hong, M.J. Comparison of automated breast volume scanning and hand-held ultrasound in the detection of breast cancer: An analysis of 5,566 patient evaluations. Asian Pac. J. Cancer Prev. 2014, 15, 9101-9105. [CrossRef]

38. Chen, L.; Chen, Y.; Diao, X.H.; Fang, L.; Pang, Y.; Cheng, A.Q.; Wang, Y. Comparative study of automated breast 3-D ultrasound and handheld B-mode ultrasound for differentiation of benign and malignant breast masses. Ultrasound Med. Biol. 2013, 39, 1735-1742. [CrossRef]

39. Hellgren, R.; Dickman, P.; Leifland, K.; Saracco, A.; Hall, P.; Celebioglu, F. Comparison of handheld ultrasound and automated breast ultrasound in women recalled after mammography screening. Acta Radiol. 2017, 58, 515-520. [CrossRef]

40. Kim, S.H.; Kang, B.J.; Choi, B.G.; Choi, J.J.; Lee, J.H.; Song, B.J.; Kim, H. Radiologists' performance for detecting lesions and the interobserver variability of automated whole breast ultrasound. Korean J. Radiol. 2013, 14, 154. [CrossRef]

41. Kim, Y.; Kang, B.J.; Kim, S.H.; Lee, E.J. Prospective Study Comparing Two Second-Look Ultrasound Techniques: Handheld Ultrasound and an Automated Breast Volume Scanner. J. Ultrasound Med. 2016, 35, 2103-2112. [CrossRef]

42. Wang, L.; Qi, Z.H. Automatic breast volume scanner versus handheld ultrasound in differentiation of benign and malignant breast lesions: A systematic review and meta-analysis. Ultrasound Med. Biol. 2019, 45, 1874-1881. [CrossRef] [PubMed] 